\title{
Water Pricing Option for Efficient Irrigated Maize Production in Kenya
}

\author{
Dennis Otieno \\ Murang'a University of Technology Kenya \\ DOI: 10.29322/IJSRP.11.08.2021.p11640 \\ http://dx.doi.org/10.29322/IJSRP.11.08.2021.p11640
}

\begin{abstract}
Due to water scarcity and unreliable rainfall regimes, irrigation plays an important role in the production of food worldwide. Farmers' willingness to pay, Scarcity and opportunity cost of water, as well as financing are key determinants of sustainability of irrigation in developing countries. There is little empirical evidence to show the consequences of irrigation water pricing based on direct survey of smallholder farmers' WTP for irrigated maize production in Kenya. This paper thus evaluated farmers' willingness to pay for irrigated maize production using cross sectional field data with the aim of establishing the value of water used in irrigated maize production. The study used Heckmanns two stage analytical framework to establish the relationship between willingness to pay and productivity of irrigated maize production. The study established that water was inefficiently used and that majority of farmers were willing to pay more than average payment made by farmers and lower than the market rates for irrigation services. It was also noted that willingness to pay for water increased with increase in irrigation rates. The study also established that farmer undervalue water when it is subsidized and that there exists a $71 \%$ inefficiency gap in maize production. the economic value of water was greater than farmers were willing to pay. This implied that farmers wasted water and that there was scope to enhance profitable of irrigated maize if only water was priced justly. Therefore, sustainable production of maize requires charging farmers market rates for water and irrigation services, training farmers and strengthening water user associations, promoting the use of efficient technology for market oriented maize production.
\end{abstract}

Index Terms- water, economic value, willingness to pay, irrigation, efficiency, profitability

\section{INTRODUCTION}

$I^{2}$ rrigation plays an important role in modernization of agriculture through increasing food productivity and production under resource-constrained environment (Sakaki and Koga, 2011; Chiroro, 2015). Variable success in irrigated crop production have been achieved through increased formulation of policies that promote improved crop productivity and production through irrigation (Kurukuklasuriya et al. 2006; Davis and Hirji, 2011; Tubiello and van der Velde, 2012; Chiroro, 2015). Globally, there is increased demand for irrigation water due to climate change with global water demand being about $50 \%$ of the 3200 million $\mathrm{m}^{3}$ of available water in Kenya (FAO 2016). Water is an essential input in food production and Kenya's rainfed mode of production experience challenges due to drought which has become more frequent and intense recurring every 2-3 years unlike in the past when it used to occur after every 10 years.

Drought has negatively impacted on the Kenya's food security and with the country relying more on food imports to meet local demand (Mekonnene and Hoekstra, 2014). Increasing import volumes have also negatively impacted on agriculture leading to low investment in in the sector, decreased agricultural productivity and production and, a general slowdown slowdown of economic development in Kenya (Otieno, et al, 2017).

Agricultural sector is the mainstay of the rural economy and grows parallel to the country's GDP and employs about $70 \%$ of the rural population directly. The sector defines the prosperity of Kenya though its contribution to national development has failed to accelerate structural shifts due to its inherent constraints (Mellor, 2008). As such, the rural areas are still have limited employment opportunities outside agriculture with the situation being worse in arid and semi-arid (ASAL) areas. Agriculture can boost rural incomes through market oriented production in the rural marginal areas when resource poor farmers have access to key factors of production such as water, land and other production assets (Mellor, 2008). Irrigation development is thus a strategy that would ensure agriculture remains main source of livelihood in rural marginal areas giving control to the local farmers and reducing leakages to non-farmers. Thus the poor would gain in terms of incomes and food self-sufficiency in an environment where increasing population, food security and changing climate are amongst the main global challenges (Beyan, Jema and Adem, 2014). Enhanced investment in irrigation in Kenya has led to rehabilitation and development of its new irrigation projects, adoption of climate smart technologies (ROK, 2010;IFRI, 2014). Studies have shown that efficient irrigation system will use less water and improve fruit production by up to $40 \%$. This goes up to between $100 \%$ and $140 \%$ increase for food production accounting about two thirds of the worlds food production (IWMI, 2002; Mueller et al, 2012; FAO, 2011).

Despite its existing potential, irrigated food production in Kenya has continued to underperform due to inefficient services, technologies and resource challenges (FAO, 2011). To reduce the effects of increased budgetary limitations on agriculture and irrigation development, the government of Kenya adopted private public partnership strategy to raise funds required to support and sustain the services offered by the National irrigation Board which implement government irrigation development plans (Otieno et al 2017). This strategy in which farmers are expected to pay subsidized statutory fees has been resisted by a large number of 
resource poor farmers who prefers paying less than the market value for water used for irrigation.

The unexpected reaction of the farmers slowed down the drive towards modernization and commercialization of agriculture as envision in agricultural transformation and growth strategy (ROK, 2018). Adoption of commercial agriculture would have would have incentivized farmers to increase production, productivity and profitability (Adesina and Baidu, 1999). Positive returns that motivate farmers to increase their investments through payments for irrigation services is thus defined as willingness to pay in this study. Studying the farmer's willingness to pay would provide evidence of what hinders their active participation in irrigation development through their willingness to pay. Therefore, this study was carried out with the aim to determine the drivers of farmer's willingness to pay decisions and their policy implication towards enhanced sustainability of irrigated maize production in Kenya.

\section{RESEARCH METHOD AND DESIGN}

As depicted in the conceptual diagram (Figure 1), the physical and socio-economic conditions of the scheme must be in harmony with the prevailing water management technology and irrigation system in the context of farmer management. These will influence key viability variables such as productivity and profitability at both the plot and scheme levels (Adesina, and Baidu-Forson, 1995, Agbamu, 1995 Burton, Rigby and Young, 1999).

At the plot level, productivity will largely depend on reliance on irrigation as income source, knowledge in farming and entrepreneurial capacity, investment initiatives and other household level variables. The driving hypothesis is that the role of these variables in influencing plot level productivity is not significant in influencing their perception and farm revenues.

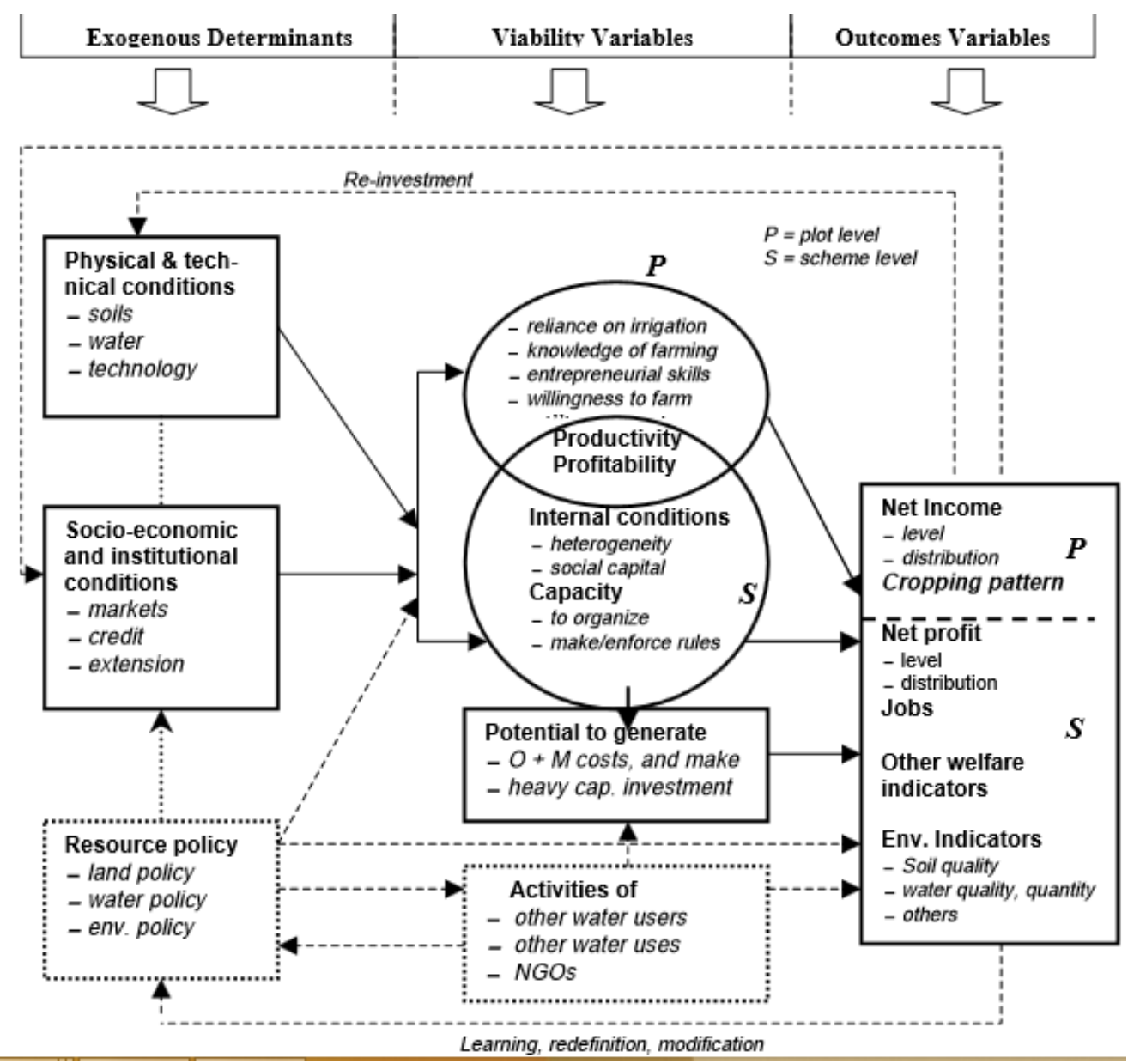

At the scheme level, viability will largely depend on the capacity to organize farmers into water users associations, manage the organization, make and enforce resource use rules and regulations, and resolve emerging conflicts. This would enable efficient supply of water throughout the scheme. This capacity is hypothesized to be affected by heterogeneity within the scheme in terms of plot sizes, income sources and social capital variables that enhance meetings and forums for discussing issues related to participatory management within the scheme (Otieno, et al, 2017).
These variables further affect the ability of the scheme to generate management and operational costs, and long-term potential to make heavy investments during periods of shocks (Otieno et al, 2017).

In addition, the activities of other water users such as large scale farmers and NGOs will affect scheme viability, either directly through their production activities, which may affect water quantity and quality, or indirectly through lobbying and social net-working to shift policy variables in their favour. The 
effect of policy variables such as land policy, water and environmental policy is felt directly or indirectly at all levels of activity, while outcome indicators may lead to policy redefinition through learning and modification. The level and distribution of net income and net profits may result in investments in new technology, and improvements in resource conditions, as well as the provision of institutional and support services (markets, credits, and training) that further enhance viability and sustainability of the scheme. This study therefore intended to provide important insights about the economic viability of irrigated maize production and farmer's perception of the same.

This study adopted a mixed method research design and was conducted in major public and private irrigation schemes in Kenya. Due to the limited number of large scale irrigation schemes in the country, the listed schemes were selected purposively. The selection criterion was based on altitude, agro ecological environments and the seasonal distribution of rains. The selected irrigation schemes were namely Bunyala, Nandi, Mwea, Upper Nzoia, Pekerra, Hola, Galana/Kulalu Hola, Lower Kuja and Bura. From the selected schemes, households were selected systematically from a list provided by the agency implementing irrigation in Kenya, NIB. Farmers who participated in the survey were selected randomly from farm clusters located at different points along the irrigation canals in all the irrigation schemes.

Data was collected using questionnaires and interview guides that defined the production structures of public and private irrigation schemes in the country using sociio-economic characteristics of the farmers, institutional support, inputs and output production and marketing relations and payments for irrigation water and services (Adesina and Baidu-Forson, 1995, Agbamu, 1995, Burton, Rigby, and Young, 1999).

The study collected information from 80 farmers, 7 focus group discussions, 19 key informants on issues covering farm level production and scheme level management activities. Secondary data was also used from existing data bases.

\section{Analytical methods}

The study used a combination of Cobb-Douglass production function and Heckman's two step regression model with a correction for selection bias (Stan and William, 2003; Yirga, 2007; Deressa et al, 2008; Kaliba et al. 2000).

The model has two equations. This first is a selection equation and the second is the substantive equation.

The algebraic representation of the Heckman's probit selection model was gives as:

$M_{i}=\emptyset x_{i}+$

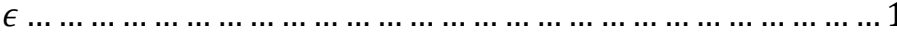

where: $\mathrm{M}_{\mathrm{i}}=$ the willingness to pay by the $\mathrm{i}^{\text {th }}$ farmer for irrigation water. $\mathrm{i}=$ the $\mathrm{i}^{\text {th }}$ vector of explanatory variables of probability of what the $i^{\text {th }}$ farmer perceives about the benefits of irrigation.

$\mathrm{x}=$ the vector of the parameter estimates of the regressors hypothesized to influence the

probability that a farmer will be incentive to perceive the benefits of irrigation bout irrigation.

Where

$\mathrm{WTP}=\mathrm{x}_{1}$, rules $=\mathrm{x}_{2}$, training $=\mathrm{x}_{3}$, end crop $=\mathrm{x}_{4}$, labour $=\mathrm{x}_{5}$, crop $=\mathrm{x}_{6}$, fert use $=\mathrm{x}_{7}$, quality $=\mathrm{x}_{8}$, water $=\mathrm{x}_{9}$, yields $=\mathrm{x}_{10}$, short crop $=\mathrm{x}_{11}$,

In the Heckman's probit outcome model, the regressor was the profit margin. It was regressed on a set of relevant explanatory variables, namely: land, fertilizer, chemical, labour, water, seeds and output. The empirical specification of the Heckman's probit outcome model was given a

$T_{i}$

$=\emptyset x_{i}$

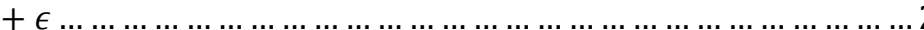

where: $T_{i}=$ the yield of the $i^{\text {th }}$ farmer from irrigated maize.

$\mathrm{i}=$ the vector of explanatory variables of probability of benefitting from irrigated maize the $\mathrm{i}^{\text {th }}$ farmer.

$\mathrm{x}_{\mathrm{i}}=$ the vector of the parameter estimates of explanatory variables hypothesized to influence the probability of farmer is benefiting from irrigated maize production

Where $\mathrm{WTP}=$ fert use $=\mathrm{x}_{7}$, water $=\mathrm{x}_{9}, \mathrm{HH}$ size $=\mathrm{x}_{12}, \mathrm{OMI}=\mathrm{x}_{13}$, Land $=\mathrm{x}_{14}$, fert $=\mathrm{x}_{15}$, skills $=\mathrm{x}_{16}$

\section{RESULTS AND DISCUSSION}

\section{FARMERS WTP FOR IRRIGATED MAIZE PRODUCTION.}

Farmers WTP discussion was elicited through Contingent Valuation (CV) questionnaire at three payment levels: <KES 3100 , KES 3100, and >KES 3100) per acre per season, to to establish their preferences. The estimated mean WTP was KES 3085 per acre per season for irrigation services with a range from KES 0 to KES 4155. The study results revealed that about $75 \%$ of the respondents, were willing to pay above the mean WTP.

The mean willingness to pay for irrigation water and services was KES 3,082 but the actual payment was KES 2,952/ acre/season. The actual payment being less than the mean WTP implied that there was a monopoly supplying irrigation services (www.ecosystem valuation 1, 2012). 


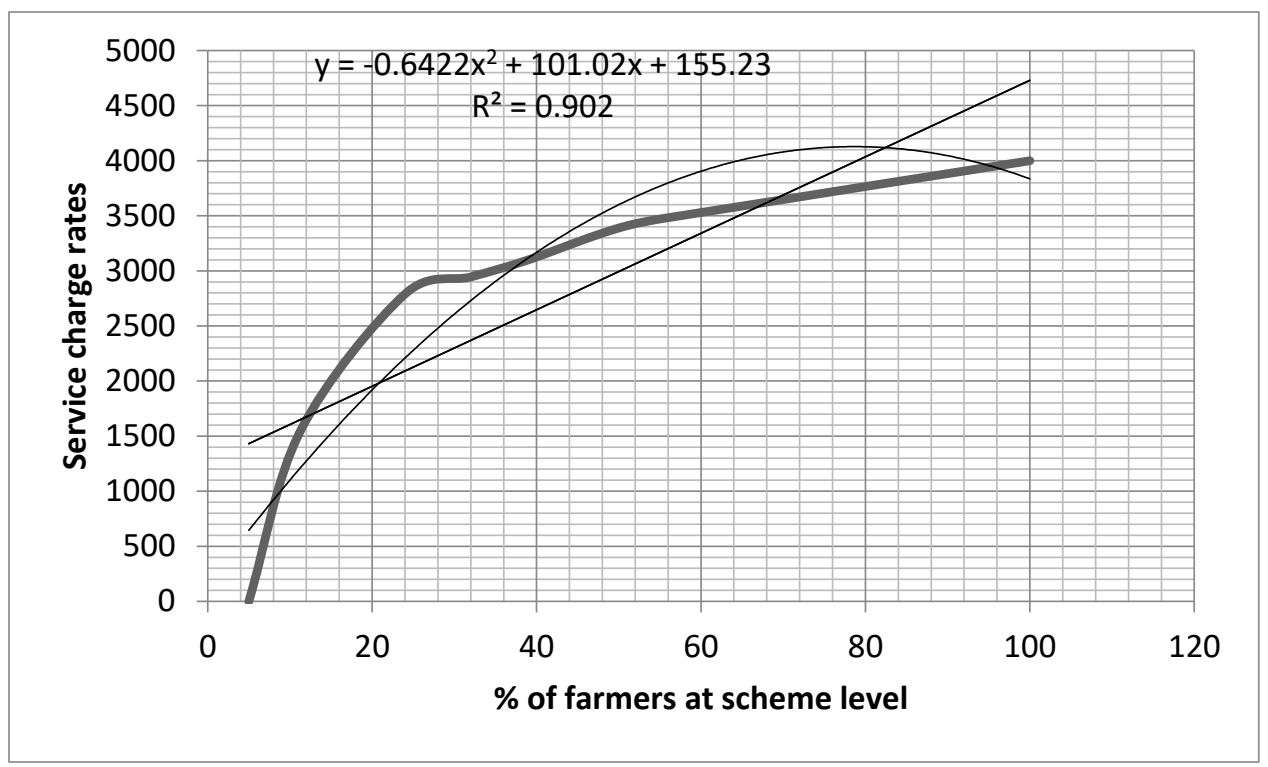

Figure 2. Distribution of farmers WTP for irrigation services.

Figure 2 shows a general increase in mean willingness to pay. In line with the theory of consumers, farmers will pay more if they perceive positive gains. This study established that irrigation is profitable and that the mean willingness to pay was greater that premium charged by the National irrigation board. More farmers were paying more than the mean willingness to pay. Figure 1 shows a a $90 \%$ goodness of data fit and that that willingness to pay follows the law of diminishing marginal utility even at farm level. It also reveals that only $24 \%$ of the farmers were paying less than the scheme level mean payment premiums or rates for irrigation water. This reveals that at low premium levels, a small number of farmers were not willing to pay for irrigation water since they found the value of water to be too low (Tang, Nan and Liu, 2012 cited Otieno, Kirimi and Odhiambo, 2015). However, it was noted that with increasing value of water, farmers were willing to pay more.

\section{Factors Influencing Farmers' WTP}

Willingness to pay and performance indices were used to establish farmers' self-evaluation of the benefits they get from maize production. This involved asking question on how scheme and plot level operations influenced their WTP decisions in relation to how much they paid. Table 3 shows the factors that influenced farmers' willingness to pay. The main factors influencing farmers' willingness to pay were income, enforcement of scheme level irrigation rules, and position along the irrigation canal
The results concur with Aheeyar (2006) who found that the 'Willingness to pay for improved irrigation services in Mahaweli' depended on the level of income with the high income earners willing to pay more for improved irrigation services. Higher incomes in this study are embedded in the Operations and Management index (O\&MI) which uses the gross margin and the costs. Regular review and enforcement of irrigation rules had a positive relations with the WTP. This is because the involvement of the farmers in the management of the scheme motivated and they directed more efforts towards the success of the scheme. Thus, they were willing to pay more for irrigation services. Once the farmers are organized into their WUAs, it becomes easy to collection of irrigation dues, review and enforce irrigation rules and regulation and distribute water among farmers with minimal conflict. Group activities instills a sense of security among farmers in using irrigation facilities and thus their willingness to pay is enhanced, produce quality, and cropping season

Without proper enforcement of scheme level rules, the position along the irrigation canal determines how much irrigation water the farmer gets. It was observed that payment increased with distance from the main water source. Labor was also a $\mathrm{n}$ important factors given that most of the work in these fields was manual. Produce quality had a negative impact on farmers' willingness to pay since low quality product fetched a low price in the market and discouraged increased production. High quality produce motivated the farmers to pay more. 
Table 1. Response of selected variable to willingness to pay and viability index

\begin{tabular}{|l|r|r|r|r|l|}
\hline & Minimum & Maximum & Mean & Std. Devia & Expected! \\
\hline Yields under irrigation are high & 3 & 5 & 4.73 & 0.629 & + \\
\hline Production is convenient & 2 & 5 & 4.7 & 0.681 & + \\
\hline Water supply schedule is good & 1 & 5 & 3.19 & 1.533 & + \\
\hline Allows for area expansion & 1 & 5 & 4.25 & 1.188 & - \\
\hline Improves quality of produce & 1 & 5 & 4.59 & 0.796 & + -- \\
\hline Reduces crop failure & 2 & 5 & 4.7 & 0.66 & + \\
\hline Reduces soil erosion & 1 & 5 & 4.26 & 1.291 & + \\
\hline Ensures efficient fertilizer use & 2 & 5 & 4.53 & 0.867 & + \\
\hline Ensures efficient manure use & 1 & 5 & 4 & 1.179 & + \\
\hline Reduces insect/ disease incidences & 1 & 5 & 3.12 & 1.607 & - \\
\hline It has a high cost & 1 & 5 & 4.44 & 1.236 & - \\
\hline It is crop specific & 1 & 5 & 2.22 & 1.766 & - \\
\hline Increases labour demand & 1 & 5 & 4.71 & 0.79 & - \\
\hline No water logging in the scheme & 1 & 5 & 3.82 & 1.522 & + \\
\hline Tail end crops receives less water & 1 & 5 & 3.16 & 1.708 & - \\
\hline Farmers are trained on new irrg skills & 1 & 5 & 3.47 & 1.591 & + \\
\hline Rules are enforced in the scheme & 1 & 5 & 3.55 & 1.344 & + \\
\hline Regular reviews & 1 & 5 & 3.68 & $1.268+$ \\
\hline Farmers have the required skills & 1 & 5 & 3.74 & 1.375 & + \\
\hline There are no conflicts btwn stakeholders & 1 & 5 & 3.12 & $1.545+$ \\
\hline Method of water distribution is the best & 1 & 5 & 3.26 & $1.608+$ \\
\hline Water is evenly distributed to all farms & 1 & 5 & 3.38 & $1.621+$ \\
\hline Irrigation has no adverse envt effect & 1 & 5 & 4.3 & 1.288 & + \\
\hline
\end{tabular}

Source field data 2015. Only significant variables are included

From this table, the key drivers of willingness have low standard deviation in which case they are yield levels; labour requirements crop failure and production convenience. Labour requirement has a negative impact meaning it's a scarce commodity in these areas. Fertilizer is an important factor of production and increased used leads to increased output with diminishing marginal productivity as more and more is used. Farmers were bund to use more fertilizer with increased number of seasons and this was a burden. The cost of production and level of fertilizer use had a negative effect on how much farmers were willing to pay (Otieno et al, 2017).

Factors occasioning low incomes in maize farming such as the need to high quality produce and low maize prices reduced the farmer's WTP. However, farmers who valued the outcomes of using irrigation water were willing to pay more. There were however some farmers who were willing to pay more than the real market price. This showed the importance of irrigation services and water in the ASAL areas.

The involvement of government in irrigated maize production through The National Irrigation Board (NIB) distorts the payment rates for irrigation water and services. The distortion maintains an artificially low price. The government initially used this strategy to promote adoption of irrigation as a modern means of production to increase productivity for improved household welfare and food security. Local experienced which majority of the farmers relies on during production decreased their likelihood of paying for irrigation water. This is due to their subsistence nature of production the associated low incomes for low quality produce despite the high demand for maize.

Training of farmers on good water management practices and better agronomic practices for maize production improved the value water they use in food production. Farmers who had better information, more learned and had better access to efficient production resources showed enhanced WTP. Studies in Nigeria, Ghana have also shown the desire of farmers to pay for irrigation services after training (Amondo, Kironchi and Wangia, 2013; Alhassan et al, 2013).

Additionally, positive attitude towards irrigated maize farming and use of modern methods of irrigated maize farming reported increased production and productivity as well as enhanced WTP. This should also involve a majority of the youths who are not participating in irrigation farming. In addition improved market access and better management of pre and postharvest loses will enhance the realization of better yields, and higher returns. These will enhance farmers' willingness to pay for irrigation services offered by the NIB. 


\section{SUSTAINABLE USE OF IRRIGATION SERVICES}

This study established that irrigated maze production is profitable. However, the results from regression analysis showed existing limitations in factor use. Inefficiency led to wastages of water, land and fertilizer in irrigated maize production at the plot level. To establish if the wastage was related to poor market pricing of water, we We used a Cobb Douglass production function to evaluate irrigated maize production trends and economic value of water. Output in bags/acre was the dependent variable was used to derive coefficients which were needed to determine. The results presented Table 2, showed that increased use of water and land would lead to a decline in output while labour, fertilizer and seed have a significant positive effect at 5\% level of significance. This shows the need to intensify land use in maize production and seek water saving technology to prevent excessive wastage of water under waterlogged production conditions. Fertilizer, seed and labour have the potential to increase output if additional amounts are used. The economic value of irrigation water was determined by employing a production function approach.

Table 2. Regression results of irrigated maize production function.

$\begin{array}{lllll} & \text { Coef. } & \text { Std. Err. } & \mathbf{t} & \mathbf{P}>|\mathbf{t}| \\ \text { Chemicals } & -0.079 & 0.089 & -0.89 & 0.378 \\ \text { Labor } & 0.116 & 0.040 & 2.85 & 0.006 \\ \text { Water } & -0.208 & 0.108 & -1.92 & 0.059 \\ \text { Seeds } & 0.604 & 0.092 & 6.56 & 0 \\ \text { Land } & -0.096 & 0.039 & -2.45 & 0.017 \\ \text { Fertilizer } & 0.092 & 0.021 & 4.39 & 0 \\ \text { _cons } & -617.78 & 361.14 & -1.71 & 0.092\end{array}$

R-squared $=0.7042$, Adj R-squared $=0.6773$

Source: Author 2015

We then determined the economic value of water using the marginal values Table 2 from table two and factor use levels at their geometric means, Table 3. The results showed that all the factors of production are inefficiently used. Seed and labor use had no significant effect on production. There was excessive and significant use of fertilizer and water while land was significantly underutilized. We therefore recommend optimal use of these resources to guarantee food security.

Table 3 Efficiency test

\begin{tabular}{|l|l|}
\hline & Water \\
\hline GM MVP & 16,852 \\
\hline Price & 4911 \\
\hline Ratio & 3.43 \\
\hline Decision & Under \\
\hline Policy direction & Increase efficiency Intensify. \\
\hline Confidence value & Significant. \\
\hline
\end{tabular}

Source Field data 2015

The study showed that for every shilling invested in irrigation, the value of maize produced was 3.43 times the value of water (Otieno et al, 2015). This showed that water was not optimally used despite farmers paying for it. The average WTP for irrigation by farmers was KES 3,808, far much lower than the opportunity cost of irrigation water of KES 9,109. A paired sample $\mathrm{t}$-test showed that there was a statistically significant difference between the two values with the marginal value product for irrigated maize being higher with a p-value $=0.035$. The implication for this is that farmers still had room to exploit the resources they were underusing to realize more returns. As such irrigated maize production is sustainable and there exists a scope to expand production through intensive use of water. Giving water free or very low water charge encourages overuse.

Pricing the inputs at their market rate may makes them more valuable when used and lead to efficient utilization. However, with subsidy, the prices of inputs are lower than their market value and this could probably the reason why farmers place low value in the use of water, fertilizer and land. This reveals market inefficiencies, where, rent seeking investors distort the input markets leading to higher cost of production and higher maize prices contrary to liberalization policy.

Policies governing the agriculture sector must be well articulated and implemented if any measure of success is to be realized. A liberal irrigation sector would motivate private investment, especially in irrigation. However, subsidizing irrigation services for farmers in a competitive production environment distorts the maize markets. This leads to a scenario where the producer surplus is larger than expected and farmers are paid for what they did not produce. While the subsidy strategy may attract the unemployed people to the rural and marginal areas to practice farming, it may impact negatively on anticipated household welfare by slowing down poverty reduction, consumption and create a dependency syndrome that may difficult to wad off under political patronage ( Topoalova, 2010).

Due to inefficiency, this study reported a low output of 11 bags per acre when the potential is as high as 20 bags implying a production gap of $71 \%$ despite irrigation being $45 \%$ more productive than non-irrigated maize, Table 3 . The economic value of water (EVW) per season per acre was KES 9,252 and KES 21,432 with the current production technology and the most efficient allocation respectively, Table 5. The farmers were paying a rate of KES 3,080 for irrigation water and services. When irrigation water is considered as a public good, the farmers can afford waste it due to its low value. 
Table 3: Maize production potential under irrigation in Kenya, 2014/2015.

\begin{tabular}{lllll} 
& \multicolumn{2}{l}{ Current technology } & Efficient technology & \\
& Season & Annual & Season & Annual \\
Efficiency & $29 \%$ & & $100 \%$ & \\
Output (Million bags) & 5.5 & 16.5 & 10 & 30 \\
Losses (Million bags) & 4.5 & 13.5 & - & - \\
EVW & 9,252 & 27,706 & 21,432 & 64,264 \\
Potential Output & $163 \%$ & & &
\end{tabular}

Source: Field data 2015

Irrigation service is a public good whose cost has been kept artificially low. This is due to the principle agent relation between the politicians and the farmers. Unless supported by other apolitical agents, this may lead to poor service delivery and poor infrastructure, especially when the public is unwilling to pay higher prices for water service that they perceive as inefficient and of low quality. While it does not maximize social welfare, it is a stable equilibrium. Vested interests from people with political power worsens the inefficiency situation and this reflects the theory of political neglect (Otieno, et al 2017).

The study established that there is scope for efficient production under irrigation with a potential to increase output by $163 \%$ under irrigation. With good agricultural practices (GAP), this translates to 20 million bags for two seasons that can improve household food security and welfare, Table 4 . The inefficiency gap is a sign of poor water management and the low value that farmers place on water. Availability of extension services to train farmers on the efficient allocation of land, water and fertilizer is important. Intensive land and water use in maize production and less fertilizer application were identified as the solution to the existing inefficiency problem. The wastage of these resources arise from the subsidy programme where farmers do not bear the full cost of production and therefore place low value on water, land and fertilizer. Therefore, to stimulate efficient use of water and other resources at their market value, a suitable water pricing mechanism should be established (Otieno et al 2017).

Sustainability of irrigation systems is very important from both farmers' and government perspectives. The increasing budgetary burden the Kenya government faces can partly be reduced by removal of subsidies. Further, the government can leverage the public private partnership arrangement to support dwindling budgetary allocations. The private sector can provide the much needed funds for irrigations $\mathrm{O} \& \mathrm{M}$ budget. This can provide improve service delivery and in irrigation schemes leading to improved crop productivity and farming income. this partnership together with local control and support for irrigation management would lower the budgetary burden of the government.

Thus, sustainable use of water is highly dependent on the value attached to water. Enhancing farmers' willingness to pay for irrigation at market rates through the support of public private partnership holds the key to sustainable irrigated maize production. It facilitates adoption of highly productive technology, farmers get higher yields and returns and thus will be able to meet all their obligations to NIB.

\section{CONCLUSION}

This study establishes that farmers undervalue water when it is subsidized and that here is a 715 inefficiency gap in irrigated maize production. The farmers' incomes are low and thus not able to pay for the irrigation and irrigation water services. The economic value of water was far much more than what the farmers were paying. Thus, there is room to increase production and profits through efficient use of water resource. If water is valued correctly, farmers will attach a greater value to it and may be willing to pay more for it. Efficient water use will enhance sustainability of irrigated maize production through increased production and increased ability of farmers to meet their obligations to NIB.

\section{Policy Implications/Recommendations}

Water is a key input in irrigation development in any country. Therefore, sustainability of irrigated maize production requires interventions in the following areas:

1. Establishing a just price in the market. Pricing water fairly at the market rate will ensure that farmers give it the right value and use it sparing avoiding loses. This will encourage irrigated maize farmers to adopt modern efficient production technology that will allow them achieve higher markets surplus. This will lead to higher returns and farmers will be able to pay the required rates for irrigation services.

2. Training will impact skills for efficient use of water leading to higher maize productivity. This will also lead to better management skills for inclusive management and enhancement of WTP for irrigation services upon appreciating the value of water in use for increased production

3. Developing partnerships and strengthening water availability through WUAs will improve water scheduling on the farms with tail end crops will get sufficient water. This ensures increased productivity

\section{REFERENCES}

[1] Adesina, A.A and Baidu-Forson, J. (1995). Farmers' Perception and Adoption of New Agricultural Technology: Evidence from Analysis in Burkina Faso and Guinea, West Africa. Agricultural economics, 13:1-9

[2] Aldrich, J. N. and Nelson, F. D. (1984). Linear Probability Logit and Probit Models. Sage University Paper Series on Quantitative Application in Social Sciences. Newbury Park:Sage Publication.

[3] Brewer, J. et al. (1999), Irrigation Management Transfer in India: Policies, Processes and Performance. Indian Institute of Managements, Ahmedabad, 
India, and the IWMI, Colombo,Sri Lanka. Oxfod and IBH Publishing Co. Pvt. Ltd.

[4] Burton, M., Rigby, D., and Young, T., (1999), Analysis of the determinants of adoption of organic horticultural techniques in the UK, Journal of Agricultural Economics 50(1):

[5] Ersado, L.,(2001). Productivity and land enhancing technologies in northern Ethiopia: Health, public investments and sequential adoption. Dissertation Submitted to the Faculty of Virginia Polytechnic Institute and State University in partial fulfillment of therequirements for the degree of Doctor of Philosophy in Economics. July 23, 2001 Blacksburg, VA 24061.

[6] FAO (2011) Flood based water irrigation n Kenya. www.spate -irrigation .org

[7] Franzel, S. (1999). Socioeconomic factors affecting the adoption potential of improved tree fallows in Africa. Agroforestry Systems 47 (1-3), 305-321.

[8] Gbetibouo, G. A. (2009). Understanding Farmers' Perceptions and Adaptations to Climate Change and Variability: The Case of the Limpopo Basin, South Africa. IFPRI Discussion Paper 00849 February 2009

[9] Hancook,r., Morciano, M and Pudney, S. (2013). Non parametric estimation of compensating variation. Th ecost of disability. No. 2013-26. Institute for science and economic research.

[10] Hatibu, N., Lazaro, E.A., Mahoo, H. F., Rwehumbiza, F. B. R., and Bakari, A. M., (1999). Soil and water conservation in semi-arid areas of Tanzania. National Policies and Local practices. Tanzania J. of Agric, Sc, 2(2): 151170.

[11] IFPRI (2014). Agricultural technology that could increase global crop yields by $67 \%$ and cut the cost of food production by half by 2050 . IFRI

[12] Inocencio, A., Kikuchi, M., Tonosaki, M.,Maruyama, A., Merrey, D., Sally, H., deJong, I., (2007). Costs and performance of irrigation projects: A comparison of sub-Saharan Africa and other developing

[13] IWMI, (2002). The Challenge of Integrated River Management in India. Water Policy Briefing Issue 3. International Water Management Institute (IWMI) -TATA Water Policy

[14] Knowler, D., Bradshaw, B. (2007). Farmers' adoption of conservation agriculture: a review and synthesis of recent research. Food Policy 32 (1), 25-48.

[15] Makhura, M. and Mamabolo, M. (2000), Socio-economic Issues in SmallScale Irrigated Agriculture: A Literature Survey of the Olifants Basin, RSA, and SADC. Report to IWMI, Sri Lanka.

[16] Makombe. G, Hagos F. Namara R.E, and Awulachew, S, B (2007) An Assessment of the financial viability and income impact of small scale irrigation in Ethiopia IWMI Ghana

[17] Mekonnen M.M and Hoekstra A.Y (2014). Water conservation through trade: A case of Kenya. Water International Journal Routledge TAYLOR AND Francis group Vol 39(4) 451-468
[18] Muelller et al (20120) International weekly journal of sciences Vol 490(7419)

[19] Ndambiri H. K., Ritho C. N. Mbogoh S. G., (2013). An Evaluation of Farmers' Perceptions of and Adaptation to the Effects of Climate Change in Kenya. International Journal of Food and Agricultural Economics ISSN 2147-8988. Vol. 1 No. 1 pp. 75-96

[20] Otieno D, Kirimi L Odhiambo N. (2015) Can irrigation be a solution to Kenyas food insecurity? Tegemeo Policy brief No 19, Egerton University.

[21] Pate, J. and Loomis J. (1997). Effects of distance on willingness to pay values. A case of wetlands and salmons in California. Journal of ecological economics 20(1997) 199- 207

[22] Programme. IWMI, Elecon, Anand-Sojitra Road, Vallabh Vidyanagar 388 001, Gujarat, India. 8pp.

[23] Rockstorm, J., Folke, C., Gordon, L., Hatibu, N., Jewitt, G., Penning de Vries, F.,Rwehumbiza, F., Sally, H., Savenije, H., and Schultze, R., (2004). A watershed approach to upgrade rainfed agriculture in water scarce regions through Water System Innovations: An integrated research initiative on water for food and rural livelihoods inbalance with ecosystem functions Physics and Chemistry of the Earth, Parts A/B/C, Volume 29, Issues 15-18: 11091118

[24] Rockstrom, J., (2001). Green water security for the food makers of tomorrow: Windows of opportunity in drought-prone savannahs. Water Science and Technology, 43 (4): 71-78.

[25] ROK, (2007) Kenya Vision 2030, Government printers, Kenya

[26] ROK (2010). Agricultural Sector development strategy,

[27] Shah, T., et al. (2001), Institutional Alternatives in African Smallholder Irrigation: Lessons From International Experience in Irrigation Management Transfer. IWMI Draft Working Paper.

[28] Svendsen, M. (1992), Assessing Effects of Policy Change in Philippine's Irrigation Performance, Working Paper on Irrigantion Performance 2, IFPRI, Washington, D. C., USA

[29] Swendsen, M. and Nott, G. (1997), Irrigation Management Transfer in Turkey: Early Experience with a National Program Under Rapid Implementation. IWMI, Colombo, Sri Lanka.

[30] Vermillion, D. (ed) (1996): The Privatization and Self-Management of Irrigation: Final Report. IWMI, Colombo. Sri Lanka.

\section{AUTHORS}

First Author - Murang'a University of Technology Kenya 